\title{
Water Quality Assessment of Keenjhar Lake, Thatta
}

\author{
Mushtaq A. Nizamani ${ }^{1 *}$, Muzafar A. Nizamani², Qadeer Khan Pahnwar ${ }^{2}$ \\ ${ }^{1}$ Faculty of Agriculture Engineering, Sindh Agriculture University Tando Jam, Pakistan \\ ${ }^{2}$ Institute of Chemistry, University of Sindh Jamshoro, Pakistan \\ ${ }^{2}$ Institute of Chemistry, University of Sindh, Jamshoro, Pakistan \\ *Corresponding Author Email: nizmani.mushtaq@gmail.com \\ $\mathrm{Ph}:+923042306780$
}

\begin{abstract}
Keenjhar Lake is the main source of drinking water for the metropolitan city of Karachi. The release of untreated wastewater from Kotri industrial area and other sources have made the lake water polluted. This study was subjected to determine the impacts of such pollutant sources on the water quality of Keenjhar Lake. The study involves the analysis of water quality parameters of Keenjhar Lake and its Feeding source (KB Feeder). The sampling sites were selected based on the sources of contamination. The water samples are tested for physical, chemical and microbiological parameters. The result of water analysis indicates the contamination level of the lake is quite alarming for the sites of Kotri effluent and WAPDA colony where Total Dissolved Solids (TDS), Chloride and other ionic metals were quite higher in concentration than other sites. These sites are also contaminated with Fluoride and Arsenic which are carcinogenic elements. The study reveals that the contamination level of feeding source is causing big nonreversible damage to the lake if continued to be uncontrolled. This contamination is mainly due to the release of toxic metals and ions in the KB feeder caused by human carelessness.
\end{abstract}

Keywords: Pollution, water quality, Keenjhar lake, environmental impacts, Physico-chemical parameters,

\section{Introduction}

Environmental degradation of addable water source is of great concern in the $21^{\text {st }}$ century. Water plays a vital role in the everyday activities of living organisms (Connel, 1974). Availability of safe and clean water is very essential. The rapid growth in population is affecting dramatically the quality of freshwater, ultimately declining availability of freshwater per capita per year.

Lakes, rivers, ponds and underground water are some most common sources of freshwater. Water in lakes and ponds is more vulnerable to environmental degradation as compared to flowing and underground water because of its steady nature (Grower, 1980). Water pollution is categorized as natural and anthropogenic, which are further classified based on their origin as point and non-point sources. Point sources pollution has some fixed source eg, effluent discharge etc. which can be identified and treated directly. While non-point source pollution is unidentifiable eg, leaching of nutrients from agricultural land etc, which are hard to identify and evaluate directly.

Lakes are open reservoirs and integrated components of the watershed. They are considered to be the chief source of freshwater. Watershed influence lakes environment and ecology which are governed by the quality of water and sediments entering, leaving or settling in the lake. Water storage period of lakes varies from months to several years. The flow of water currents within the lake is multidirectional and many lakes have alternating periods of stratification and vertical mixing. (Connel, 1974)

Keenjhar lake plays a vital role in providing fresh water to the city of Karachi and Thatta for domestic and commercial purposes. This water is used for recreational activities, industrial usage, drinking purpose and gardening and agriculture. The lake is fed by KB feeder originating from river Indus via Kotri barrage. The anthropogenic pollution sources contaminating the lake water are KB feeder and lake itself. KB canal faces various effluent discharge points before releasing its water to Keenjhar Lake (SUPARCO, 2012). The effluent waste of industries operating in Kotri industrial area is discharged into the canal without proper treatment. The other potential pollution sources for the canal water is the municipal waste of WAPDA Colony and domestic waste of villages located along with the canal. Keenjhar Lake has also various sources of pollution located at various points within the lake. The sources of contamination include wastewater of houses and population living within it. The waste originating from agricultural fields and cattle farm located within the range of Keenjhar Lake. The waste of Sindh Irrigation Department Rest House near the lake is also contaminating lake water to some extent.

\section{Experimental Work:}

\subsection{Material and Methods}


Grab water samples were collected from the top, centre and bottom of the sampling sites for physicochemical analysis of the samples. The composite of the sample was made by adding them to each other. Pre sterilized sampling bottles of 200-500 $\mathrm{mL}$ capacity/borosilicate glass used for microbial sampling.

The parameters to be used in the analysis are Temperature, pH, Total Dissolved Solids, Electrical Conductivity, Turbidity, Calcium, Bicarbonate, Alkalinity, Hardness, Magnesium, Potassium, Sodium, sulfate, Fluoride, Chlorides, Arsenic, Dissolved Oxygen (DO), E-Coli and Total Coliform. These parameters are analyzed according to the method defined by the American Public Health Association (APHA) manual for drinking water and wastewater. Water samples were analyzed at the drainage and reclamation institute of Pakistan under soil and water analysis lab. Tando Jam.

The temperature was measured with a mercury thermometer at concern sites; alkalinity was detected with titration (Sulfuric acid), chloride with (silver nitrate). Water samples for the determination of dissolved oxygen (DO) samples were determined with DO meter on site. Electrical conductivity (TDS) was determined with a WTW LF 320 conductivity meter. Standard titration methods (Framan, 1981; APHA, 1998) were used to determine total dissolved solids and $\mathrm{pH}$ with an Orion model $420 \mathrm{pH}$ meter. Turbidity was determined by Sacchi disk method, calcium was determined by EDTA titration method, magnesium by EDTA titration method, potassium and sodium through flame photometer, sulfate and fluoride was determined by colourimeter DR/890, hardness was determined by EDTA titration method, Arsenic was determined by Kit method, E-Coli and total-Coliform were determined by membrane filtration (MF) method.

\subsection{Site Selection}

The sampling points were selected to be one which was badly contaminated. The non-point sources sampling stations are being selected based on the location of the station that serves as a feeding and extracting of the lake. While for point sources, the stations are selected according to the discharge of the effluent from industrial areas which directly drain to the KB Feeder. The points of sampling were taken from point sources i.e. $\mathrm{KB}$ canal which is the feeding source of freshwater for Keenjhar lake. The industrial effluent waste of Kotri industrial area is discharged into the canal this is one of the major sources of anthropogenic contamination of lake water. Other potential point sources of pollution are a municipal waste of WAPDA Colony and domestic waste of villages settled along the canal. The sampling points are indicated in table 1 .

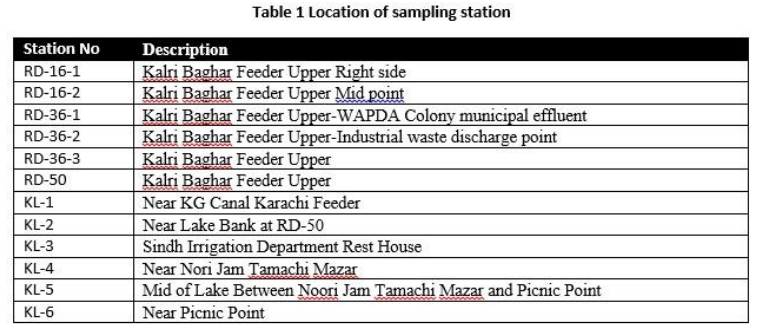

\section{Results and Discussion}

The analysis of water quality parameters is based on the World Health Organization (WHO) standards and standards set by Pakistan Council for Research in Water Resources (PCRWR) for the physio-chemical parameters for the drinking water. The American Public Health Association (APHA) standard and was used for the determination of drinking water quality parameters. No Guideline Values Set (NGVS). The WHO standards were used for the assessment of biological parameters of water. Table 2

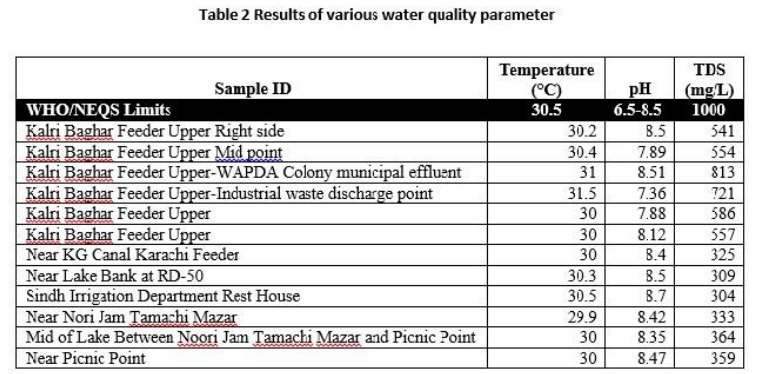

Table 2 indicates the results of various water quality parameters with comparison to National Environmental Quality Standards (NEQS) limits. Here the NEQS limits are given at the top of the table. The parameters which are given in this table include Temperature (Temp.), pH, and Total Dissolved Solids (TDS).

Table 3

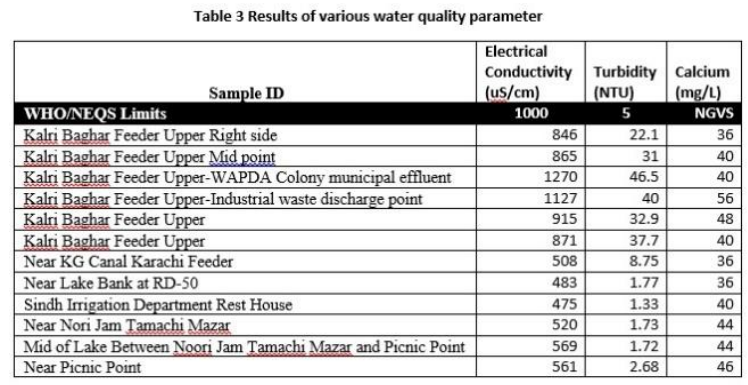

Table 3 indicates the results of various water quality parameters with comparison to NEQS limits. Here the NEQS limits are given at the top of the table. The parameters which are given in this table include Electrical Conductivity (EC), Turbidity, and Calcium. 


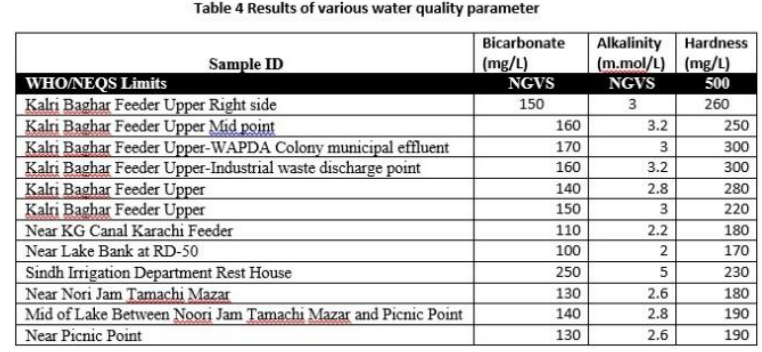

Table 4 indicates the results of various water quality parameters with comparison to NEQS limits. Here the NEQS limits are given at the top of the table. The parameters which are given in this table include Bicarbonate, Alkalinity and Hardness.

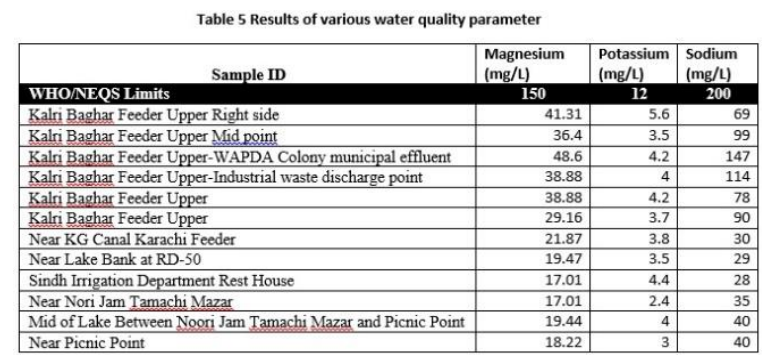

Table 5 indicates the results of various water quality parameters with comparison to NEQS limits. Here the NEQS limits are given at the top of the table. The parameters which are given in this table include Magnesium, Potassium, and Sodium.

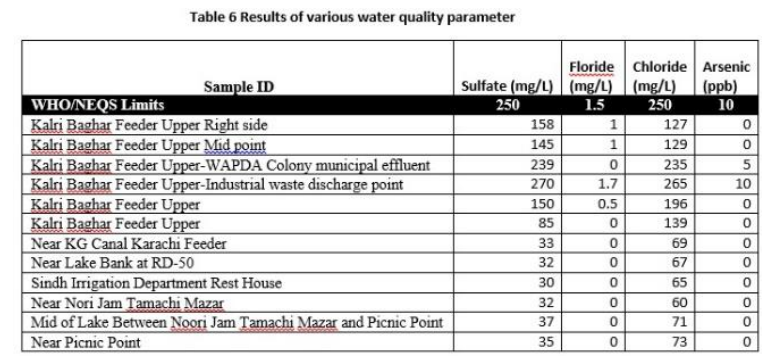

Table 6 indicates the results of various water quality parameters with comparison to NEQS limits. Here the NEQS limits are given at the top of the table. The parameters which are given in this table include Sulfate, Fluoride, Chloride and Arsenic.

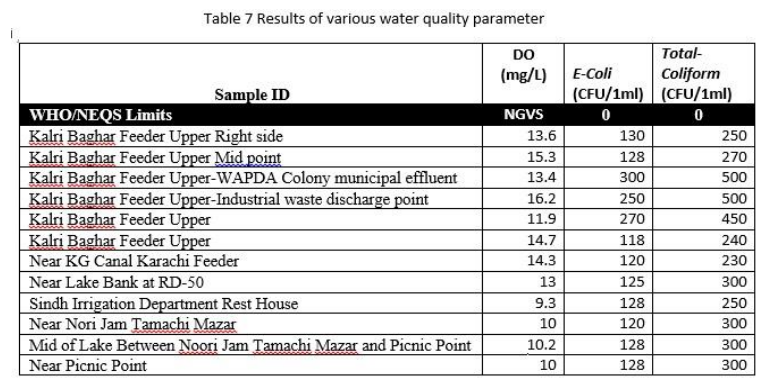

Table 7 indicates the results of various water quality parameters with comparison to NEQS limits. Here the NEQS limits are given at the top of the table. The parameters which are given in this table include Dissolved Oxygen (DO), E-coli, and Total Coliform.

\subsubsection{Temperature $\left({ }^{\circ} \mathrm{C}\right)$}

The values of Temperature are recorded at selected sampling stations for KB Feeder and Keenjhar Lake and are plotted in figure 1 .

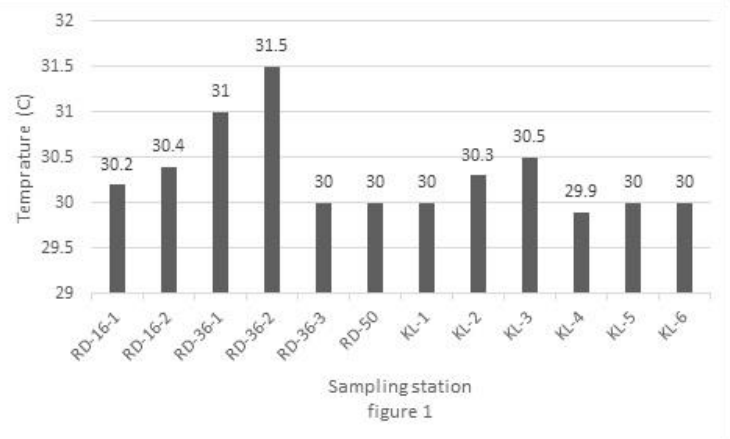

the higher values of temperature are found for the site RD-36-1 and RD-36-2 where WAPDA colony municipal Waste and Kotri industrial area effluent inflows to KB Feeder. For the above-mentioned sites, the values of temperature are higher than the NEQS limits while for all the other sites the values of temperature are within safe limits. The higher values might be due to disposal of hot industrial water from various thermal plants and cooling chambers of industries. The lower values for lake water could be due to thermal stratification and restricted mixing of layers.

\subsubsection{PH}

The values of $\mathrm{pH}$ are recorded at selected sampling stations for $\mathrm{KB}$ feeder and Keenjhar Lake and are plotted in figure 2 .

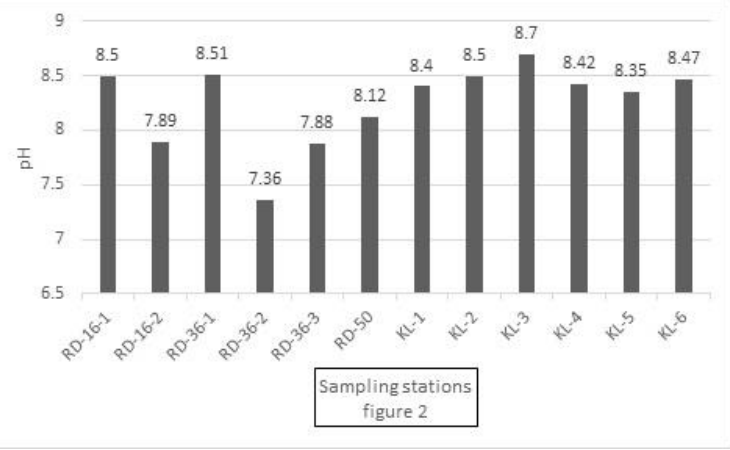

the higher value of $\mathrm{pH}$ is found for the site KL-3 where Sindh Irrigation Department Rest House is located. The value found for the above mentioned site is 8.7 higher than the NEQS limit. While the average value 
of $\mathrm{pH}$ for Keenjhar Lake is higher than the average value of $\mathrm{pH}$ for $\mathrm{KB}$ Feeder. The reason behind this could be the occurrence of various layers of Calcium Bi Carbonate in the Lake. High Bicarbonate values are ultimately responsible for the increase in $\mathrm{pH}$.

\subsubsection{Total Dissolved Solids (TDS)}

The values of TDS are recorded at selected sampling stations for $\mathrm{KB}$ Feeder and Keenjhar Lake and are plotted in figure 3.

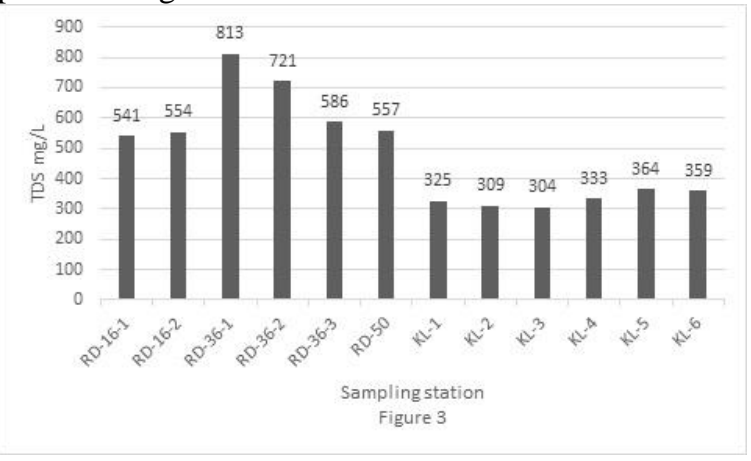

the higher values of TDS are found for station RD-36 particularly at substation RD-36-1 where WAPDA colony municipal waste inflows into the KB Feeder. All the sites have TDS values within safe limits. The values of TDS are quite stable for Keenjhar Lake as it has stationary water. The settling of suspended and dissolved solids has made no fluctuations in TDS values for the lake while $\mathrm{KB}$ Feeder has certain flowing speed so its values fluctuate.

\subsubsection{Electrical Conductivity (EC)}

The values of Electrical Conductivity are recorded at selected sampling stations for KB Feeder and Keenjhar Lake and are plotted in figure 4.

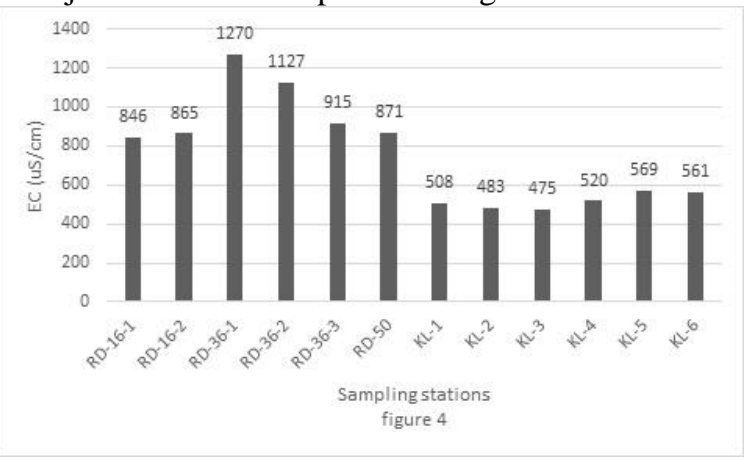

the higher values of Electrical Conductivity (EC) are found for station RD-36 particularly at substation RD36-1 where WAPDA colony Municipal waste inflows into the KB Feeder. All the sites have values of EC within safe limits. Electrical Conductivity (EC) shows a significant correlation with Total Dissolved Solids
(TDS). There is no reliable data available on the health effects of Electrical Conductivity (EC) in drinking water but $1500 \mathrm{micro}-\mathrm{S} / \mathrm{cm}$ is considered to be standard value. The Values of EC are quite stable for Keenjhar Lake as it has stationary water. The settling of salts (Calcium, Magnesium, Sodium, and Potassium) and carbonate has made no fluctuations in Electrical Conductivity values for the lake while KB Feeder has certain flowing speed so its values fluctuate.

\subsubsection{Turbidity}

The values of Turbidity are recorded at selected sampling stations for KB Feeder and Keenjhar Lake and are plotted in figure 5 .

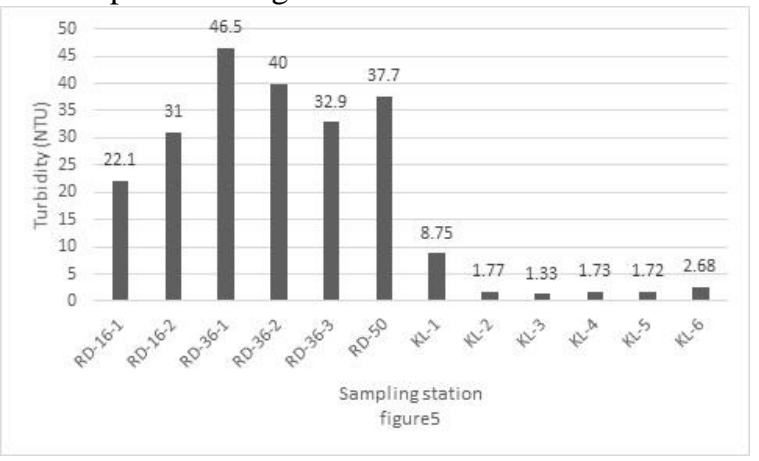

higher values of turbidity are found for KB Feeder particularly for site RD-36-1. The values of Turbidity for $\mathrm{KB}$ Feeder are higher than the safe limits. The values found in Keenjhar lake are within safe limits and also are quite stable. The higher values for KB Feeder could be due to the reason that KB Feeder has a high concentration of suspended clay and silt particles. Their movement with flowing water makes water cloudy ultimately causing for severing turbidity. The Keenjhar lake is a calm reservoir having a velocity of 0.001 to 0.1 meter per second causes turbid water of KB Feeder to be settled down in different layers.

\subsubsection{Calcium}

The values of Calcium are recorded at selected sampling stations for KB Feeder and Keenjhar Lake and are plotted in figure 6 . 


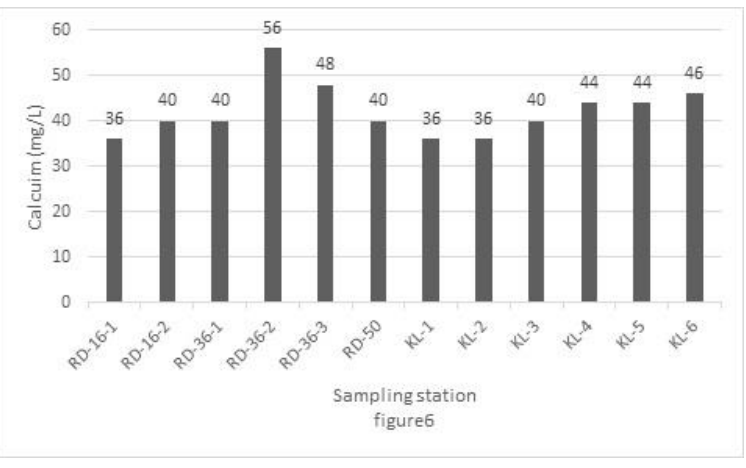

a higher value of calcium is found at RD-36-2 where the effluent inflow of Kotri industrial area occurs to KB feeder. While for all the other sites, the value of Calcium is appropriate from a drinking point of view. Guideline value for Calcium is not defined but drinking water must have within the range of $40-50$ $\mathrm{mg} / \mathrm{L}$.

\subsubsection{Bicarbonate}

The values of Bicarbonate are recorded at selected sampling stations for KB feeder and Keenjhar lake and are plotted in figure 7 .

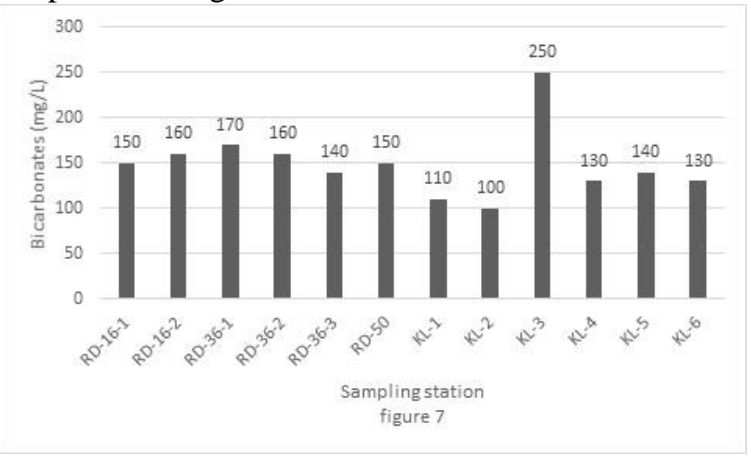

A higher value of Bicarbonate is found to be at KL-3 point in Keenjhar lake which is near Sindh Irrigation Department Rest House. While for all the other sites, they are quite stable. All the value as within safe limits.

\subsubsection{Alkalinity}

The values of Alkalinity are recorded at selected sampling stations for KB Feeder and Keenjhar Lake and are plotted in figure 8.

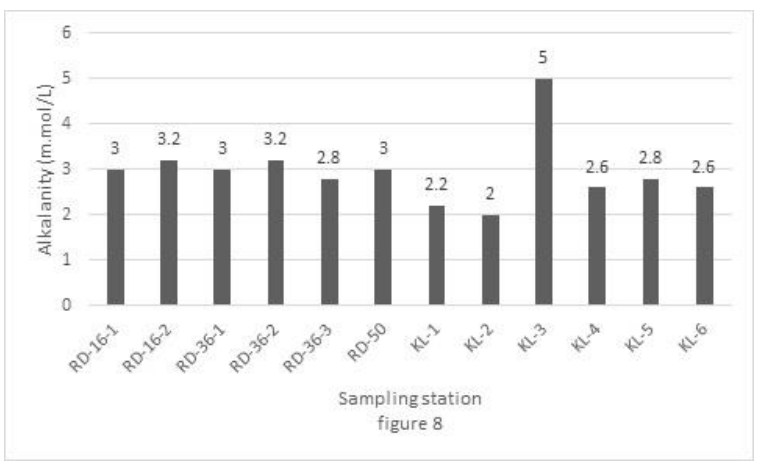

A higher value of Alkalinity is found to be at KL-3 point in Keenjhar Lake which is near Sindh Irrigation Department Rest House. While for all the other sites, they are quite stable. All the value as within safe limits. Alkalinity is composed of Carbonate and Bicarbonate that why it has analogues results to Bicarbonate. Alkalinity act as a stabilizer for $\mathrm{pH}$. The high value of $\mathrm{pH}$ is found also for KL-3 point located in Keenjhar Lake. The result indicates this location has a higher concentration of Calcium ores.

\subsubsection{Total Hardness}

The values of Hardness are recorded at selected sampling stations for KB feeder and Keenjhar lake and are plotted in figure 9 .

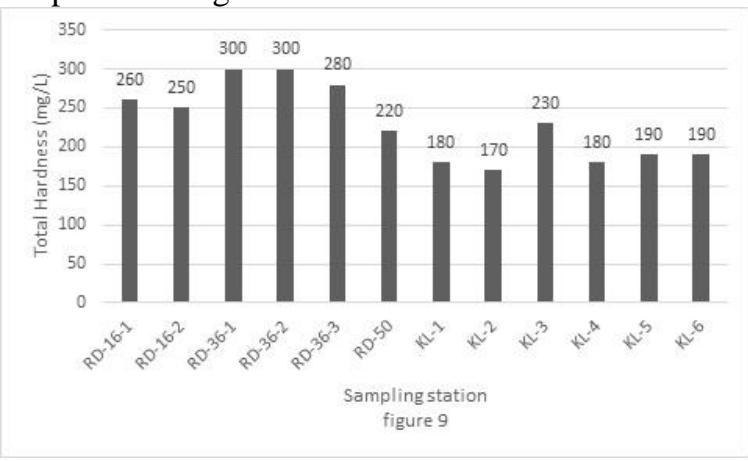

Higher values are found for KB feeder while lower and quite stable values are found for Keenjhar lake. The station RD-36 where WAPDA colony municipal waste and Kotri industrial area effluent inflows are located has a higher concentration than other sites. Hardness in drinking water is mainly caused by the presence of various salts. The settling of those salts across the lake water may have decreased the overall concentration for the lake.

\subsubsection{Magnesium}

The values of Magnesium are recorded at selected sampling stations for KB Feeder and Keenjhar Lake and are plotted in figure 10. 


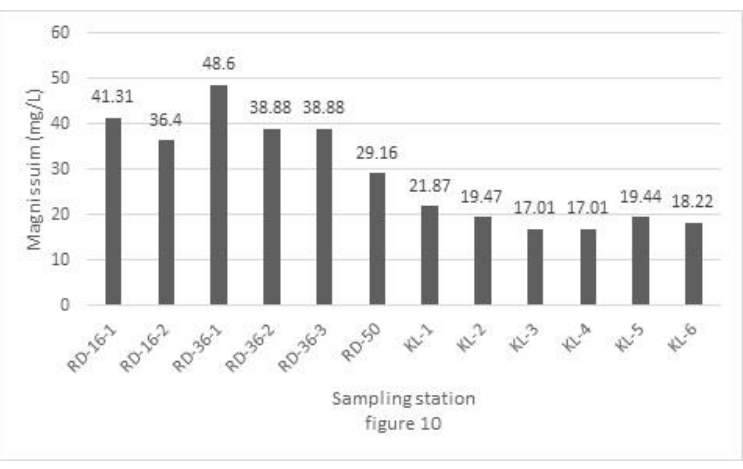

higher values are found for KB feeder particularly for site RD-36-1, where the municipal waste of WAPDA colony inflows into the canal. This anthropogenic contamination has lower effects on Keenjhar lake water where settling of magnesium salts reduce its overall strength. All the values are within safe limits and no significant impact could be considered for magnesium on lake water.

\subsubsection{Potassium}

The values of Potassium are recorded at selected sampling stations for KB feeder and Keenjhar lake and are plotted in figure 11.

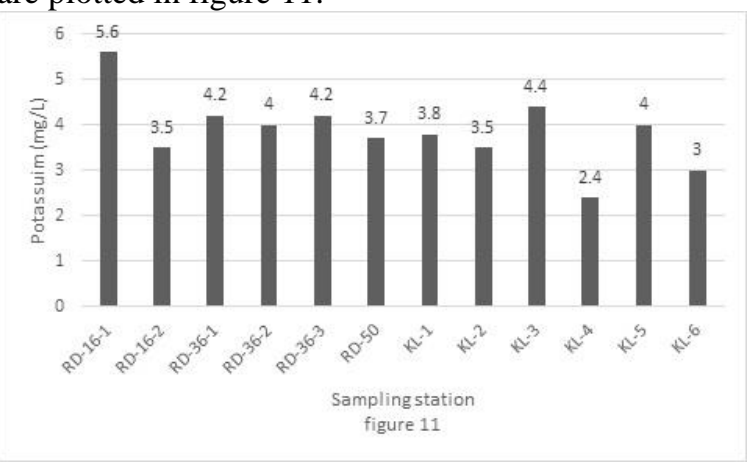

A higher value is found for RD-16-1 which is the origin point of KB feeder. This location lies near the shore of KB Feeder having a higher concentration of Potassium caused by soil runoff and sewage inflows. The value is found quite stable for all the other sites except KL-4 which lies near nori Jam Tamachi at Keenjhar Lake. The lower value for this point may be due to high depth of Lake at this point. Potassium is an essential element in human nutrition so no limit is set while WHO recommends $12 \mathrm{mg} / \mathrm{L}$.

\subsubsection{Sodium}

The values of Sodium are recorded at selected sampling stations for KB Feeder and Keenjhar lake and are plotted in figure 12.

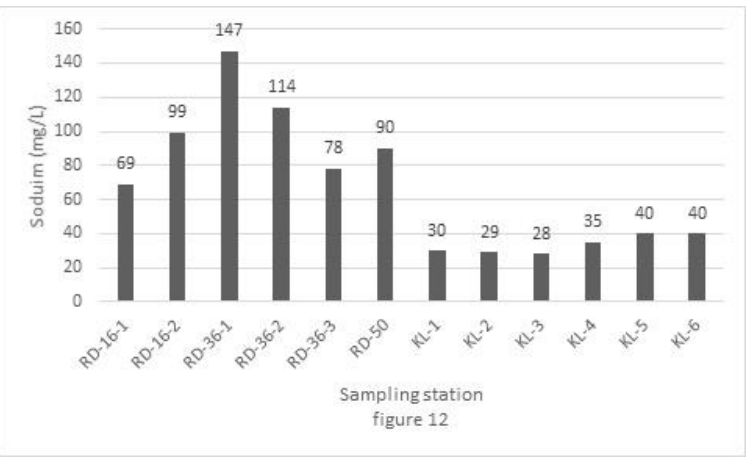

Higher values of Sodium are found for KB feeder especially for RD-36-1, where WAPDA municipal colony is located. The main source of sodium for drinking water is municipal, industrial and erosion inflows. The lower values are found for Keenjhar and they are quite stable for all the sites. The content of Sodium is not regulated while the WHO recommended value for sodium is $200 \mathrm{mg} / \mathrm{L}$.

\subsubsection{Sulfate}

The values of Sulfate are recorded at selected sampling stations for KB feeder and Keenjhar Lake and are plotted in figure 13.

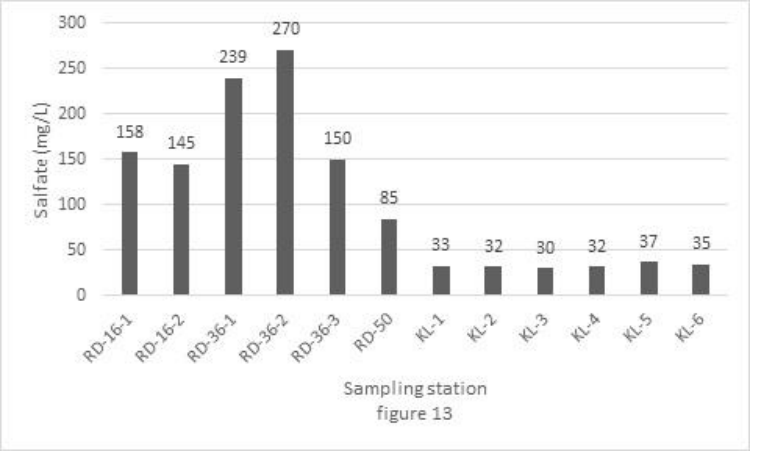

Higher values of sulfate are found for $\mathrm{KB}$ feeder especially at RD-36-2 where industrial effluent of Kotri industrial area is discharged into KB feeder. The sulfate occurs in natural water due to erosion of rocks and soil, atmospheric precipitation and from industrial sewage. The lower values are found for Keenjhar lake which is stable for all the sites.

\subsubsection{Fluoride}

The values of Fluoride are recorded at selected sampling stations for KB Feeder and Keenjhar Lake and are plotted in figure 14 . 


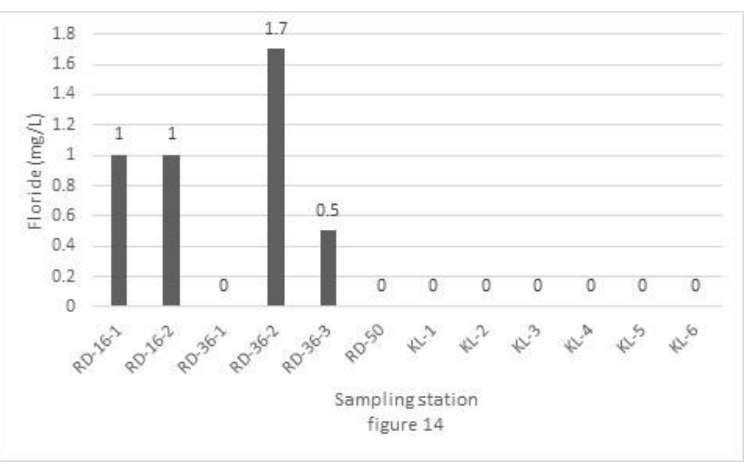

Higher values of Fluoride are found at RD-36-2 where Kotri industrial area inflows to KB feeder. The value found for the above site is higher than safe limits. A higher concentration of fluoride is very harmful to humans. No fluoride is found for Keenjhar lake due to settling of fluoride ion in Keenjhar Water.

\subsubsection{Chloride}

The values of Chloride are recorded at selected sampling stations for KB Feeder and Keenjhar Lake and are plotted in figure 15 .

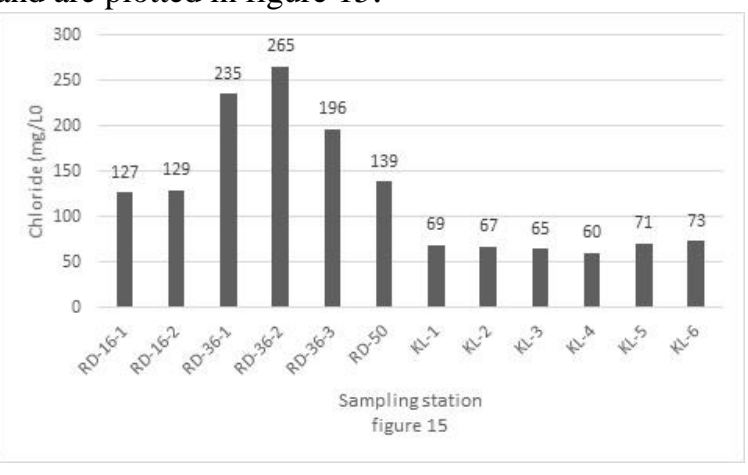

Higher values of chloride are found at station RD-36, where effluent water inflows to the canal. The main source of chloride is sewage and industrial wastewater. The value found at RD-36-2 where Kotri industrial water inflows to the canal are higher than the safe limits while all the other sites of KB feeder has values within safe limits. Lower and quite stable values are found for Keenjhar lake which are within safe limits. These stable values for lake might be due to settling of chloride ions in Lake Bottom. Here equal distribution can be due to very low velocities in deep water.

\subsubsection{Arsenic}

The values of Arsenic are recorded at selected sampling stations for KB feeder and Keenjhar lake and are plotted in figure 16 .

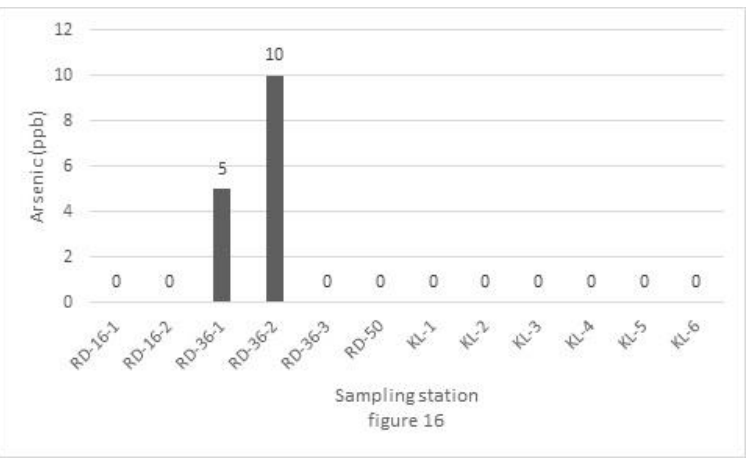

Arsenic is found only for two sites of $\mathrm{KB}$ feeder while its concentration for Keenjhar lake water was zero. The arsenic was found for the sites RD-36-1 and RD36-2, where WAPDA Colony waste and Kotri industrial area effluent inflows to lake respectively. The higher values of arsenic can cause severe skin problems.

\subsubsection{Dissolved Oxygen}

The values of Dissolved Oxygen are recorded at selected sampling stations for KB feeder and Keenjhar lake and are plotted in figure 17.

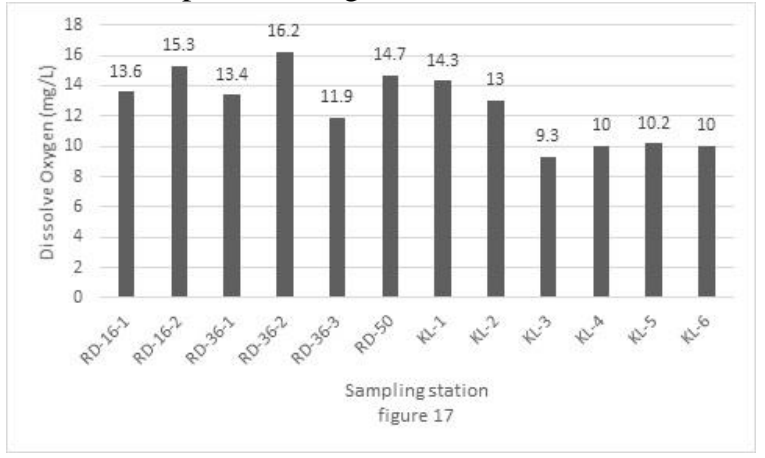

Higher values of dissolved oxygen were found for KB Feeder while lower were found for Keenjhar lake. All the values were within safe limits. The higher values in KB Feeder might be due to the reason of flowing water has high dissolved oxygen level as compared to stagnant water because water movement increases the surface area of water so that water having more surface area has higher chances to come in contact of air. No guideline values are set for Dissolved Oxygen but 5 $\mathrm{mg} / \mathrm{L}$ is considered to be standard value.

\subsubsection{E-coli}

The values of $E$-Coli are recorded at selected sampling stations for $\mathrm{KB}$ feeder and Keenjhar lake and are plotted in figure 18 . 


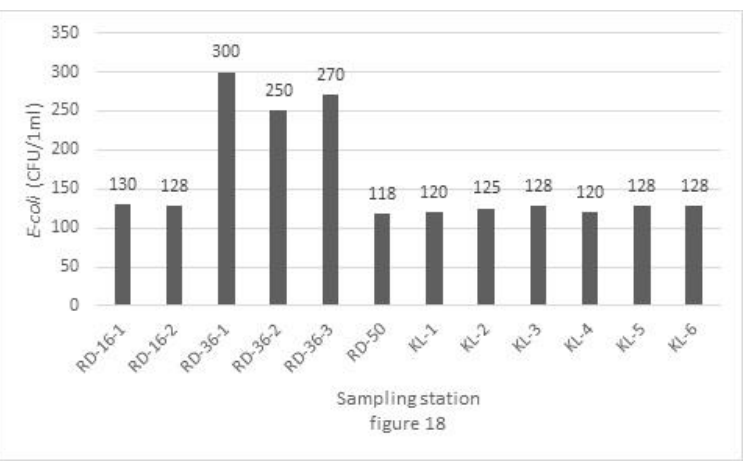

higher values of $E$-Coli are found in $\mathrm{KB}$ feeder particularly for station RD-36 where human and animal waste inflow occur while lower and quite stable values are found for Keenjhar lake. The value for KL-6 and KL-3 point have high E-Coli than other sites in Keenjhar Lake because the area is located near picnic point and Sindh Irrigation Department respectively. We found some cattle farms and villages along the bank of the canal near RD-36 so it might be possible that this increase in value for abovementioned sites could be due to disposal of their waste to the canal. Lake water is not safe to drink without any treatment because according to WHO Standards drinking water must have zero E-Coli.

\subsubsection{Total Coliform}

The values of Total Coliform are recorded at selected sampling stations for KB Feeder and Keenjhar Lake and are plotted in figure 19.

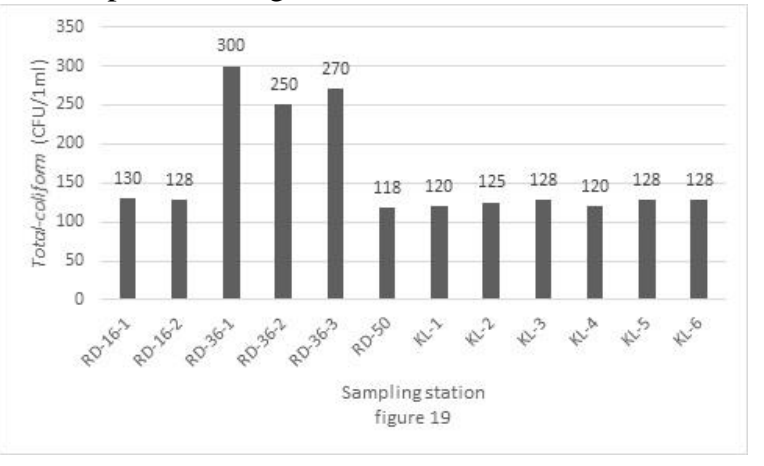

higher values of Total coliforms are found in $\mathrm{KB}$ feeder particularly for station RD-36 where human and animal waste inflow occur while lower and quite stable values are found for Keenjhar lake. The value for KL-6 and KL-3 point have high Total Coliform than other sites in Keenjhar lake because the area is located near Picnic point and Sindh Irrigation Department respectively. We found some cattle farms and villages along the bank of the canal near RD-36 so it might be possible that this increase in value for above-mentioned sites could be due to disposal of their waste to the canal. Lake water is not safe to drink without any treatment because according to WHO Standards drinking water must have zero Total Coliforms.

\section{Conclusion}

The result indicates $\mathrm{KB}$ feeder is the main point where pollution accumulates due to wastewater discharge of anthropogenic pollution sources. This untreated wastewater feeding to $\mathrm{KB}$ feeder ultimately contaminated the freshwater of Keenjhar Lake on which aquatic and human life relies. Higher Alkalinity and $\mathrm{pH}$ value of Keenjhar Reserve near Sindh Irrigation Dept. rest House (KL3) provides a most favourable environment for Biological activities so it is concluded that municipal Waste of rest house is a big menace for Lake Water. The lower DO value indicates the accumulation of nutrients at the bottom of Lake causing abrupt growth of Harmful Algae.

The analysis of water quality parameters indicates that higher values of Temperature were found for the site RD-36-1 and RD-36-2 where WAPDA colony municipal waste and Kotri industrial effluent water inflows occur. The values were higher than NEQS limits. The values found for $\mathrm{pH}$ were higher for Keenjhar Lake whereas quite fluctuating for $\mathrm{KB}$ Feeder. The parameters like Total Dissolved Solids (TDS), Electrical Conductivity (EC), Turbidity, Hardness, Magnesium, Sodium, Sulfate, Fluoride, Chloride, Arsenic, Dissolved Oxygen, E-coli and Total Coliform were found higher for KB feeder water while lower for Keenjhar lake water. The higher values for $\mathrm{KB}$ feeder could be due to flowing water and nearness to pollution sources whereas stationary water at Keenjhar lake causes these parameters to be settled down.

The levels of Electrical conductivity, Total Dissolved Solids (TDS), Hardness, Chloride $\left(\mathrm{Cl}^{{ }^{-}}\right)$, Sulfate $\left(\mathrm{SO}_{4}\right)^{2^{-}}$, Nitrate $\left(\mathrm{NO}_{3}\right)^{1^{-}}$and Total Coliform were found higher in a sample of RD-36 where Kotri industrial area effluent and WAPDA Colony wastewater flows.

The water quality parameters of the lake are within safe limits as given by Pak NEQS. Dissolved Oxygen (DO) value was measured near KG Canal where lake water has an exit which could be because of the occurrence of organic species in the lake. Moreover, E. coli and Fecal coliform bacteria were also detected in each water sample which makes lake unfit to use for drinking purposes without treating.

Finally, we can conclude that Keenjhar Lake water is deteriorating. 


\section{References}

APHA. (2000). Standard Methods for Examination of Water and Wastewater. Washington, DC: APHA.

Connel, D. (1974). Water pollution cause and effects in Australia. Queensland: University of Queensland Press.

D, C. (1996). Water Quality Assessment: A Guide to the Use of Biota, Sediments and water in environmental monitoring. UK: Chapman \& Hall Ltd.

Grower, A. (1980). Water quality in the catchment Ecosystem. Institution of environmental sciences series.

Khalid H. Lashari, S. H. (2014). "The effects of physicochemical parameters on planktonic species population of Keenjhar lake, district Thatta, Sindh, Pak. American Journal of BioScience.

SUPARCO. (2012). Water quality assessment and characterization of toxicity of keenjhar lake. Karachi: SUPARCO.

R. K. Singh, N. P. Srivastava and V. R. Desai. J. Int. Fish. Soc. India. 12 (1980) 100. 9.

M. Y. Khuhawar and G. M. Mastoi. J. Anal. Environ. Chem. 3 (1995) 66. 10.

S. Nazneen, F. Bano, S. K. Hassan and F. Begum. Pak. J. Sci. and Indus. Res. 43 (2000) 226. 11.

A. R. Zafar. Hydrobiologia. 23 (1964 a) 179. 12.

S. M. Das and V. K. Srivastava. Proc. Nat. Ascad. Sci. India, 26 (4) (1956) 243. 13.

R. N. Singhal, J. Swarn and R. W. Davis. Proc. Indian. Acad. Sci. (Anim. Sci.) 95(3) (1986) 353. 14.

F. Rutne. Fundamentals of Limnology. University of Toronto Press. (1963) P 295. 15.

I. S. Jayangoudar and S. V. Ganapati. Hydrobiol. 26 (1965) 317
R. K. Singh, N. P. Srivastava and V. R. Desai. J. Int. Fish. Soc. India. 12 (1980) 100. 9.

A. Kumar, C. Bohra and A. K. Singh. Daya publishing House, Delhi, India, 1 (2000) 149. 19.

M. G. George. Proc. Indian Acad. Sci. 569 (1962) 345. 20.

S. R. Verma, A. K. Tyagi and R. C. Dalela. Hydrobiology. 30 (1978) 96. 21.

S. C. Shukla, R. Kant and B. D. Tripathi. Geo. Bios. 16 (1989) 20. 22.

R. K. Singh, N. P. Srivastava and V. R. Desai. J. Int. Fish. Soc. India. 12 (1980) 100. 23.

S. M. Leghari, S. I. H. Jafri, M. A. Mahar, K. H. Lashari, S. S. Ali, T. M. Jahangir and M. Y. Khuhawar. J. of Biological Sci. 3 (2000) 1904. 24. K. J. Rao. Studies on the seasonal and diet variation in some physico-chemical condition of a pond under prawn culture proceeding Natural Symposium Fish and Environ. (1986) 96. 25.

C. B. Rao. On the distribution of algae in a group of six small ponds. J. Ecol. 43 (1955) 291. 26.

S. S. Singh and L. A. Singh. J. Environ. Biol. 21 (3) (2000) 273. 27.

R. G. Wetzel. Limnology. Second edition. Saunders College Publ. Philadelphia (1983). 28.

T. M. Jahangir, M. Y. Khuhawar, S. M. Leghari, W. A. Baloch, A. A. Leghari and A. Leghari. Pak. J. Biol. Sci., 3 (2000) 1965. 